\title{
Interaction between biological and chemistry fungicides and tomato pollinators
}

\section{Interacción entre fungicidas biológicos y químicos con polinizadores de tomate}
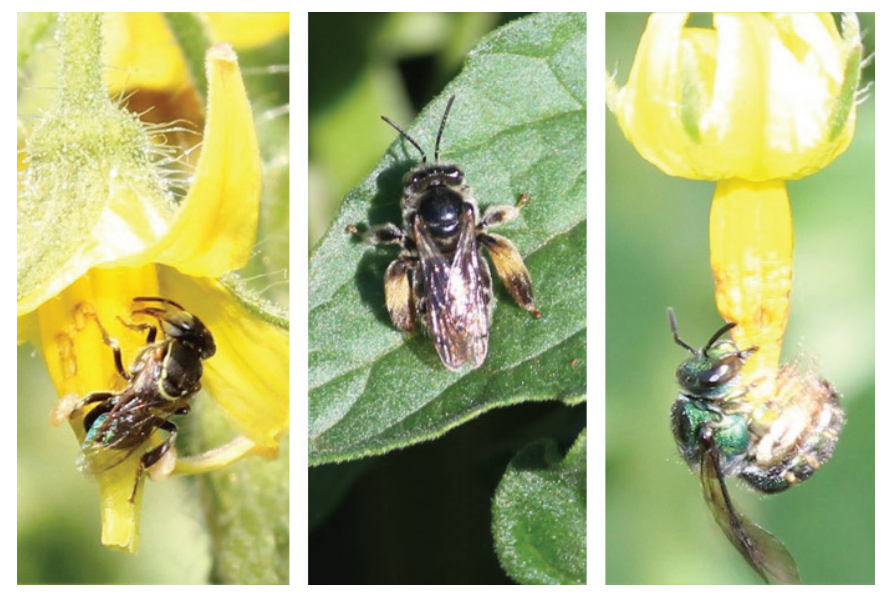

CARLOS DE MELO E SILVA-NETO'1,7

ANNA CLARA CHAVES RIBEIRO ${ }^{2}$

FLAVIANA LIMA GOMES ${ }^{3}$

JORDANA GUIMARÃES NEVES ${ }^{4}$

ANIELA PILAR CAMPOS DE MELO 5

FRANCINE NEVES CALIL ${ }^{6}$

ABADIA DOS REIS NASCIMENTO 4

EDIVANI VILLARON FRANCESCHINELLI ${ }^{3}$

Paratrigona lineata (left), Exomalopsis analis (center), Augochloropsis sp. (right). Tomatos flower and leaf.

Photo: C.d.M.e Silva-Neto

\begin{abstract}
The use of agrochemicals is harmful to bees visiting agricultural crops, reducing production gains from pollination, but the effect of fungicides on these bees is not known. The objective of this study was to verify the effect of bee visitation influenced by different fungicides on the tomato crop and on the deposition of pollen grains on the stigma, number of seeds, mass and fruit size. The experiment was conducted with 10 treatments: (T1) control treatment, without application of agrochemicals; (T2 and T3) Bacillus subtilis in different application frequencies; (T4) copper hydroxide; (T5) B. subtilis and copper hydroxide; (T6) acibenzolar-S-methyl; (T7) (trifloxystrobin + tebuconazole) and B. subtilis; (T8) copper hydroxide+Mancozeb; (T9) propineb+(trifloxystrobin+tebuconazole); (T10) (trifloxystrobin+tebuconazole) + B. subtilis + copper hydroxide. The presence of the pollination mark on the flower, the pollen load of the stigmas, the number of seeds per fruit, and the size and mass of the fruits were determined in each treatment. Subsequently, the mortality rate of Melipona quadrifasciata (Hymenoptera, Apidae) exposed to four fungicides (trifloxystrobin + tebuconazole; manganese and zinc; copper hydroxide; Bacillus subtilis) was estimated. The mortality rate of $M$. quadrifasciata over $24 \mathrm{~h}$

1 Laboratório de Sementes e Coleções Biológicas, Instituto Federal de Goiás (IFG), Goias-GO (Brazil). ORCID Silva-Neto, C.d.M.e.: 0000-0001-8624-3836

2 Instituto de Ciências Biológicas, Universidade Federal de Goiás, Goiânia-GO (Brazil). ORCID Ribeiro, A.C.C.: 0000-0002-0335-0407

3 Instituto de Ciências Biológicas, Laboratório de Biologia Reprodutiva de Plantas, Universidade Federal de Goiás, Goiânia-GO (Brazil). ORCID Gomes, J.G.: 0000-0003-2824-0180; ORCID Franceschinelli, E.V.: 0000-0001-9050-8577

4 Escola de Agronomia, Universidade Federal de Goiás, Goiânia-GO (Brazil). ORCID Neves, J.G.: 0000-0001-8102-3236; ORCID Nascimento, A.d.R.: 0000-0003-3952-5878

5 Campus Avançado Cristalina, Instituto Federal Goiano, Cristalina-GO (Brazil). ORCID Melo, A.P.C.d.: 0000-0002-5687-5928

6 Escola de Agronomia, Setor de Engenharia Florestal, Universidade Federal de Goiás, Goiânia-GO (Brazil). ORCID Calil, F.N.: 0000-0003-2882-9622

7 Corresponding author.carloskoa@gmail.com
\end{abstract}


of evaluation was higher in the treatments with copper hydroxide and trifloxystrobin +tebuconazole (75 and 50\%, respectively). The mortality rate was lower in the treatments with manganese and zinc and Bacillus subtilis and in the control treatment. The treatments with trifloxystrobin+tebuconazole reduced the presence of bite marks on the flowers and of pollen grains on the flower stigma. The fruits of the control treatments and treatments with $B$. subtilis and copper hydroxide were larger and had greater mass, as compared to other agrochemicals. Thus, a higher number of pesticide applications on the tomatoes reduced bee visitation rates to the flowers and, consequently, reduced the amount of pollen grains deposited on the stigmas, also reducing the fruit production.

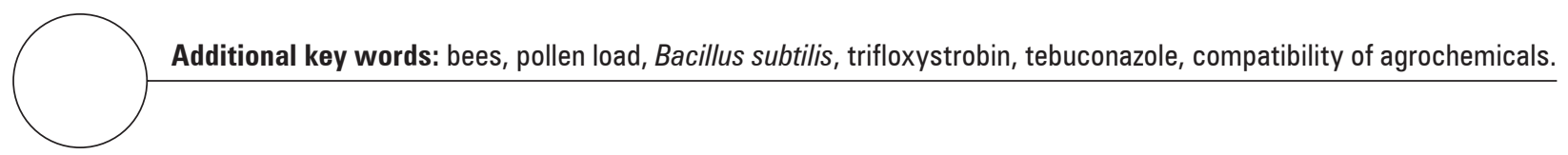

\section{RESUMEN}

El uso inapropiado de agroquímicos es perjudicial para las abejas que visitan los cultivos agrícolas, lo que reduce la producción por la afectación de la polinización y son pocos los estudios sobre este tema. El objetivo de este estudio fue verificar la incidencia de diferentes fungicidas sobre la visita de abejas en cultivos de tomate y sus efectos sobre la deposición de granos de polen en el estigma, número de semillas, masa y tamaño del fruto. Los experimentos consistieron en 10 tratamientos que fueron: (T1) tratamiento control sin agroquimicos; (T2 y T3) Bacillus subtilis en diferentes frecuencias de aplicación; (T4) hidróxido de cobre; (T5) B. subtilis e hidróxido de cobre; (T6) acibenzolar-S-metilo; (T7) trifloxistrobina + tebuconazol y B. subtilis; (T8) hidróxido de cobre + Mancozeb; (T9) propineb +(trifloxistrobina +tebuconazol); (T10) (trifloxistrobina + tebuconazol) +B. subtilis +hidróxido de cobre. Se determinó la presencia de la marca de polinización en la flor, la carga de polen en los estigmas, el número de semillas por fruto, y el tamaño y masa de los frutos en cada tratamiento. Posteriormente, se estimó la tasa de mortalidad de Melipona quadrifasciata expuesta a cuatro fungicidas (trifloxistrobina+tebuconazol, manganeso y zinc, hidróxido de cobre, Bacillus subtilis). La tasa de mortalidad de M. quadrifasciata en 24 horas de evaluación fue mayor en los tratamientos con hidróxido de cobre y trifloxistrobina + tebuconazol (75 y 50\%, respectivamente). La tasa de mortalidad fue menor en los tratamientos con manganeso y zinc, Bacillus subtilis y el tratamiento de control. Los tratamientos con trifloxistrobina y tebuconazol redujeron la presencia de marcas de mordida y granos de polen en el estigma de las flores. Los frutos de los tratamientos control y con B. subtilis e hidróxido de cobre fueron más grandes y tuvieron mayor masa. Por lo tanto, un mayor número de aplicaciones de pesticidas en las plantas de tomate reducen las tasas de visitas de abejas en las flores y en consecuencia, la cantidad de granos de polen depositados en los estigmas afectando también la producción de los frutos.

Palabras clave adicionales: abejas, carga de polen, Bacillus subtilis, trifloxystrobin, tebuconazol, compatibilidad de agroquímicos.

Received for publication: 01-02-2018 Accepted for publication: 30-05-2018

INTRODUCTION

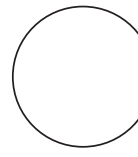

Tomato crops are associated with a wide range of pathogens: bacteria, fungi, viruses and nematodes present throughout the plant. Currently, at least nine fungal diseases, five bacterial diseases, and six viral diseases have been defined for tomato crops in addition to nematode attacks and eight different types of insect pests (Silva-Neto et al., 2013). Chemical control through the use of pesticides (insecticides, fungicides, nematicides, acaricides) is the main management method in tomato production systems in Brazil and in the world (Vale et al., 2013).

The annual consumption of agrochemicals in Brazil surpasses $300,000 \mathrm{t}$ of formulated products, representing over 130,000 t of active ingredients. The consumption of agrochemicals has increased $700 \%$ in the last 40 years, while the agricultural area grew by only $78 \%$, showing an increase in the consumption of 
agrochemicals per production area; 899,000,000 L of pesticides were sprayed in crops in only three Brazilian states (Mato Grosso, Paraná and Rio Grande Sul) (Fletcher and Barnett, 2003; Spadotto et al., 2004; Pignati et al., 2017). However, we emphasize that the inappropriate use of products can be extremely negative for the biological systems found in cultivated areas, which include biotic (pollinators, natural enemies and vegetation) and abiotic components (water and soil) (Freitas et al., 2009).

The main cause of the reduced number of pollinators in crops is the abusive or inappropriate application of agrochemicals. The indiscriminate and irrational use of agrochemicals in agroecosystems can unbalance the population of bees that visit these sites (Rocha, 2012). Insecticides cause acute toxicity, killing bees, and may also cause behavioral changes in individuals, which over time, causes serious damage to colony maintenance (social) or to populations of para-social or solitary bees (Rocha, 2012).

Among pesticides, neonicotinoids present a large problem for the pollination process. This class of insecticides is absorbed by plants, contaminating the pollen and nectar grains that are consumed by pollinators. In addition, even plants that were not treated can absorb chemical residues through soil previously treated with neonicotinoids (Hopwood et al., 2012) because of the long residual action. Gill and Raine (2014) reported that exposure to neonicotinoid and pyrethroid pesticides cause acute and chronic damage to the foraging activity of Bombus terrestris L. (Hymenoptera, Apidae) bees in the United Kingdom, leading to changes in behavior that are detrimental to colony survival and pollination. There is a high consumption of pesticides in Brazil, and their effects on pollinators are still unknown. Tomato crops, although autogamic, are pollinated by several bees. These bees carry out buzz pollination, clinging to the anther cone and vibrating it (leaving a mark on the pollinated flower). The vibration expels pollen from the anthers and increases the deposition of pollen grains on the stigma of the flower (pollen load). Thus, in addition to feeding on pollen from flowers, bees help increase production and the quality of fruits (Silva-Neto et al., 2013; Silva-Neto et al., 2016).

There is general concern about how insecticidal pesticides may affect pollinating bees and agricultural production (Hopwood et al., 2012). However, other classes of agrochemicals have not been studied because they do not affect pollinators directly. Nevertheless, fungicides can be lethal and/or sublethal to bees (Riedl et al., 2006). Johnson et al. (2013) emphasized that fungicides alone are not considered highly toxic to Apis mellifera (Hymenoptera, Apidae), but also stressed that when this group of pesticides is combined with other groups, the toxicity of the components increases, causing more damage to bees. Degrandi-Hoffman et al. (2015) showed that bees that fed on pollen contaminated with fungicide (Pristine group -pyraclostrobin + boscalid) presented sub-lethal effects of malnutrition, increased amount of viruses and higher pathogen susceptibility. However, Artz and Pitts-Singer (2015) observed that Rovral 4F (iprodione) and Pristine, fungicides commonly used in agricultural crops in California (USA), disturbed the orientation of two solitary bee species (Osmia lignaria and Megachile rotundata, Hymenoptera, Megachilidae), hindering return trips to the hive. In view of the above, the objective of this study was to estimate the effects of fungicides on the mortality of Melipona quadrifasciata bees, on the in-field pollination of flowers and on the formation of tomato fruits.

\section{MATERIALS AND METHODS}

\section{Study areas}

The experiment was conducted under field conditions in the garden of the School of Agronomy of the Federal University of Goiás (16 $35^{\prime} 48^{\prime \prime} \mathrm{S}$ and $49^{\circ} 16^{\prime} 53^{\prime \prime}$ W, altitude of $709 \mathrm{~m}$ ), municipality of Goiânia-GO, from November, 2014 to January, 2015. The climate is classified as Aw according to the Köppen classification and is characterized by a dry winter and rainy summer (Peel et al., 2007). Annual rainfall is approximately $1,487.2 \mathrm{~mm}$. The soil has a medium texture and is classified as Dystrophic Oxisol (Embrapa, 2006).

\section{Experiment design and implementation}

The experiment was conducted in a randomized blocks design, with 10 treatments (Tab. 1) and four replicates (flowerbed A, B, C and D). The "Italian tomato" tomato hybrid (Feltrin ${ }^{\circledR}$ ) was used. Each plot consisted of eight plants with $30 \mathrm{~cm}$ spacing, two planting lines per plot, and $1 \mathrm{~m}$ wide flowerbeds. The flowerbeds were covered with black mulch. The seedlings were transplanted $30 \mathrm{~d}$ after sowing on November 13, 2014. A bamboo and wire tutoring system was installed in the beds to support the tomato plants, and a 
drip irrigation system was used. Liming and fertilization procedures were carried out before planting the seedlings in addition to the cover fertilizer used after planting, following the soil analysis results. The first leaf spray was performed 8 days after transplanting (dat) (November 21, 2014), and the subsequent sprays occurred at weekly or fortnightly intervals (Tab. 1).

\section{Pollen load of the flowers}

The flowers were collected and fixed in FAA $80 \%(90 \%$ formaldehyde, $5 \%$ alcohol $80^{\circ} \mathrm{GL}$ and $5 \%$ acetic acid) in December, 2014 at 70 dat to compare the amount of pollen grains in the stigma of the flowers of the plants exposed to the different treatments $(n=20$ per treatment). Then, the stigmas were separated and placed in $9 \mathrm{~N} \mathrm{NaOH}$ for $1 \mathrm{~h}$, and were stained with acetic acid and observed under an optical microscope.

The number of pollen grains in each stigma was counted in three fields of vision under an optical microscope (40× magnification). The fields of vision were the two opposing ends of the stigma and its central part (Dafni et al., 2005).

The presence of marks left by the jaws of bees on the anthers of the flowers during their visits was also observed. This mark is an important indication that bees that perform buzz pollination in poricidal anthers have visited. For this, the anther was observed under a stereoscopic microscope, where the mark was observed for its presence and the distance from the mark until the opening of the anthers' cone was measured using a millimeter paper as reference (Morandin et al., 2001a; 2001b; Silva-Neto et al., 2013).

\section{Fruit characterization}

Three tomatoes were collected per plant, amounting to 15 units per treatment (January, 2015, 90 dat), to evaluate the effect of pollination on fruit formation and production. The mass of the total fresh weight was measured on a precision scale $(0.001 \mathrm{~g})$ using gravimetry. The seeds were separated in Petri dishes and counted with a manual counter. The height and diameter of the fruits were evaluated using a digital caliper.

\section{Bee mortality experiment}

The Mandaean bees [(Melipona quadrifasciata (Lepeletier)] came from the hives of the School of Agronomy of the Federal University of Goiás, Goiânia-GO (16 $6^{\circ} 5^{\prime} 16.39^{\prime \prime} \mathrm{S}$ and 49 $\left.17^{\prime} 32.56^{\prime \prime} \mathrm{W}\right)$. The bees were collected using a pooter and each colony was isolated in separate containers. Therefore, each colony was a replicate of the experiment. Samples of 10 to 15 bees

Table 1. Fungicides used and intervals of application in the different treatments performed with tomato (Solanum Iycopersicum) crops in the municipality of Goiânia-GO, Brazil.

\begin{tabular}{|c|c|c|c|c|}
\hline Number & Treatments & Active ingredient & Dosage/ha & Foliar applications \\
\hline $\mathrm{T} 1$ & Control & No products & - & - \\
\hline $\mathrm{T} 2$ & Serenade ${ }^{\circledR}$ & Bacillus subtilis & $2.00 \mathrm{~L}$ & 12 foliar applications at weekly intervals \\
\hline T3 & Serenade $^{\circledR}$ & Bacillus subtilis & $2.00 \mathrm{~L}$ & Six foliar applications at fortnightly intervals \\
\hline T4 & Kocide $^{\circledR}$ & Copper hydroxide & $1.0 \mathrm{~kg}$ & 12 foliar applications at weekly intervals \\
\hline T5 & $\begin{array}{l}\text { Serenade }^{\circledR} \\
\text { and Kocide }\end{array}$ & Bacillus subtilis + copper hydroxide & $2 \mathrm{~L}+1 \mathrm{~kg}$ & $\begin{array}{l}\text { Weekly product alternation, in a total of six } \\
\text { applications each }\end{array}$ \\
\hline T6 & Bion $^{\circledR}$ & Acibenzolar-S-methyl & $0.005 \mathrm{~kg}$ & Six foliar applications at fortnightly intervals \\
\hline $\mathrm{T7}$ & $\begin{array}{l}\text { Nativo }^{\circledR} \text { and } \\
\text { Serenade }^{\circledR}\end{array}$ & $\begin{array}{l}\text { (Trifloxystrobin + tebuconazole) } \\
+ \text { Bacillus subtilis }\end{array}$ & $0.75+2.00 \mathrm{~L}$ & $\begin{array}{l}\text { Weekly product alternation, in a total of six } \\
\text { applications each }\end{array}$ \\
\hline T8 & $\begin{array}{c}\text { Kocide }^{\circledR} \text { and } \\
\text { Manzate }^{\circledR}\end{array}$ & Copper hydroxide + mancozeb & $1+3 \mathrm{~kg}$ & $\begin{array}{l}\text { Weekly product alternation, in a total of six } \\
\text { applications each }\end{array}$ \\
\hline T9 & $\begin{array}{c}\text { Antracol }^{\circledR} \\
\text { and Nativo } \\
\end{array}$ & $\begin{array}{l}\text { Propineb + (trifloxystrobin } \\
+ \text { tebuconazole) }\end{array}$ & $3 \mathrm{~kg}+0.75 \mathrm{~L}$ & $\begin{array}{l}\text { Weekly product alternation, in a total of six } \\
\text { applications each }\end{array}$ \\
\hline $\mathrm{T} 10$ & $\begin{array}{l}\text { Nativo }^{\circledR} \text { and } \\
\text { Serenade }^{\circledR} \\
\text { and Kocide }\end{array}$ & $\begin{array}{c}\text { (Trifloxystrobin + tebuconazole) } \\
+ \text { Bacillus subtilis + copper hydroxide }\end{array}$ & $0.75 \mathrm{~L}+2 \mathrm{~L}+1 \mathrm{~kg}$ & $\begin{array}{l}\text { Weekly product alternation, in a total of four } \\
\text { applications each, and four applications of } \\
\text { Kocide }^{\circledR} \text { after the others }\end{array}$ \\
\hline
\end{tabular}


per container with four replicates were used for each pesticide, plus the control. Thus, there were four samples with about 40 to 50 bees per treatment, amounting to over 200 bees. The collected bees rested for an hour, and the feeding consisted only of sugar syrup before they started feeding on food with added pesticide. The experiment procedure was performed in the laboratory under controlled conditions, with a temperature of $24^{\circ} \mathrm{C}$.

Each container consisted of a clear, 1,000-mL plastic pot with part of its lid cut and replaced with a screen for ventilation (Fig 1). The containers were kept in the laboratory in a dark environment with a controlled temperature $\left(20\right.$ to $\left.25^{\circ} \mathrm{C}\right)$. Four agrochemical fungicides in addition to the control were evaluated, namely: Nativo ${ }^{\circledR}$ (trifloxystrobin+tebuconazole); Mancozeb $^{\circledast}$ (manganese and zinc); Kocide ${ }^{\circledast}$ (copper hydroxide), and Serenade ${ }^{\circledR}$ (Bacillus subtilis). For each treatment, $50 \mathrm{mg}$ of product were used in solution with sugar syrup (50\%) at $3 \mathrm{~mL}$ in a $15 \mathrm{~mL}$ tube cap for the first feeding, replacing only the syrup every 24 h (adapted from Johnson et al., 2013).

The mortality and behavior (alimentation, motility and orientation) of the bees were checked every $3 \mathrm{~h}$, except between $10 \mathrm{pm}$ and $7 \mathrm{am}$. The number of dead bees was recorded for $54 \mathrm{~h}$, and the values were used to calculate the mortality rate (percentage of dead bees divided by the total number of bees).

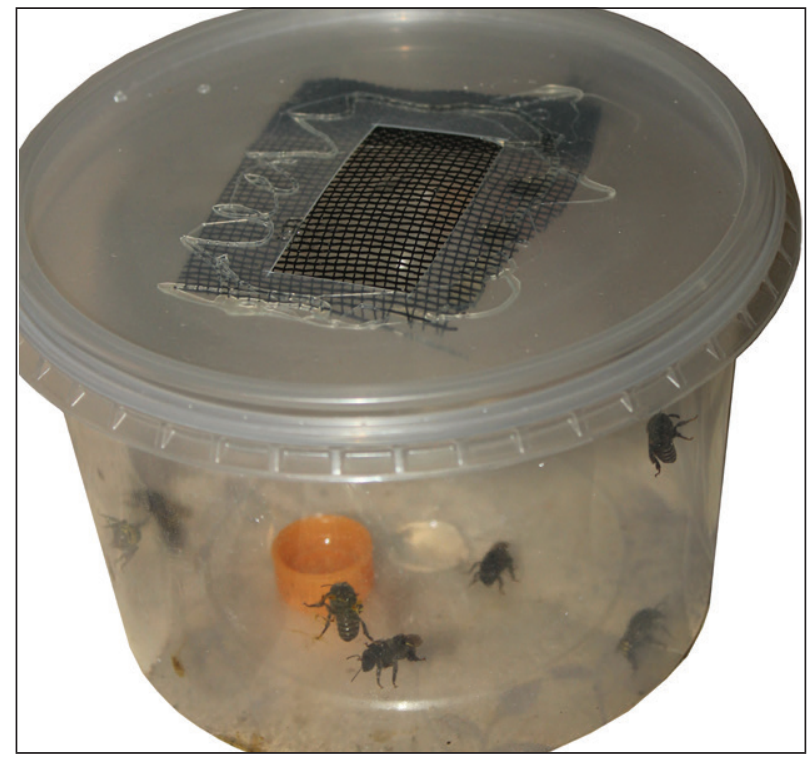

Figure 1. Plastic container with fungicide associated with the diet of bees from the species Melipona quadrifasciata.

\section{Statistical analysis}

The significance of the effect of the treatments was determined with an F-Test. A Tukey multiple comparison test with a statistical significance of $95 \%$ was used. A principal component analysis (PCA - correlation matrix) was used to characterize the different treatments simultaneously. To perform the analyzes, we used the software Past 2.17.

A polynomial regression analysis was carried out to assess the mean mortality rate over time, observing the best fit in the curve and considering a statistical significance of $95 \%$ for each treatment. The mortality rates of the different treatments, at 24 and $48 \mathrm{~h}$ of evaluation, were compared using an analysis of variance with Tukey's multiple comparison test (95\%).

\section{RESULTS}

The mortality rate for Melipona quadrifasciata, during $24 \mathrm{~h}$ of evaluation, was higher for copper hydroxide $(75 \%)$ and trifloxystrobin+tebuconazole $(50 \%)$. However, the mortality rate for manganese (2\%) and zinc, B. subtilis (19\%) and the control treatment $(2 \%)$ did not differ from each other $(\mathrm{F}(2 ; 22)=66,461$; $P=0,0000)$. The higher mortality rates for the 48 -hour evaluation period were observed for copper hydroxide (88\%) and trifloxystrobin+tebuconazole (55\%), while the mortality rates for the other treatments were the same as that recorded for the $24-h$ period (F=6.72; GL=8; $P=0.0001$ ) (Fig. 2).

The treatments with fungicides, copper hydroxide and trifloxystrobin + tebuconazole exerted an acute effect, with increasing mortality rate up to $24 \mathrm{~h}$, killing most of the bees. From $30 \mathrm{~h}$ on, the mortality rate stabilized until reaching $54 \mathrm{~h}$ of evaluation. The fungicides that caused the highest mortality, before killing all the bees, caused reactions, such as repetitive behaviors, imbalance and diarrhea (Fig. 3).

The fungicide (active principle), the dosage and the frequency of application all affected bee pollination and, consequently, fruit production $\{\mathrm{F}(10.315)=2.823$; $P=0.002\}$. Lower pollen loads in the flower stigma were recorded for treatments 7 (trifloxystrobin + bacillus), 9 (propineb+trifloxystrobin + tebuconazole) and 10 (trifloxystrobin + tebuconazole + B. subtilis + copper hydroxide), consisting of 100 grains of pollen, less than the combination of copper and Mancozeb. All of the treatments had the chemical compound trifloxystrobin although the the combination of compounds varied (Tab. 2). 


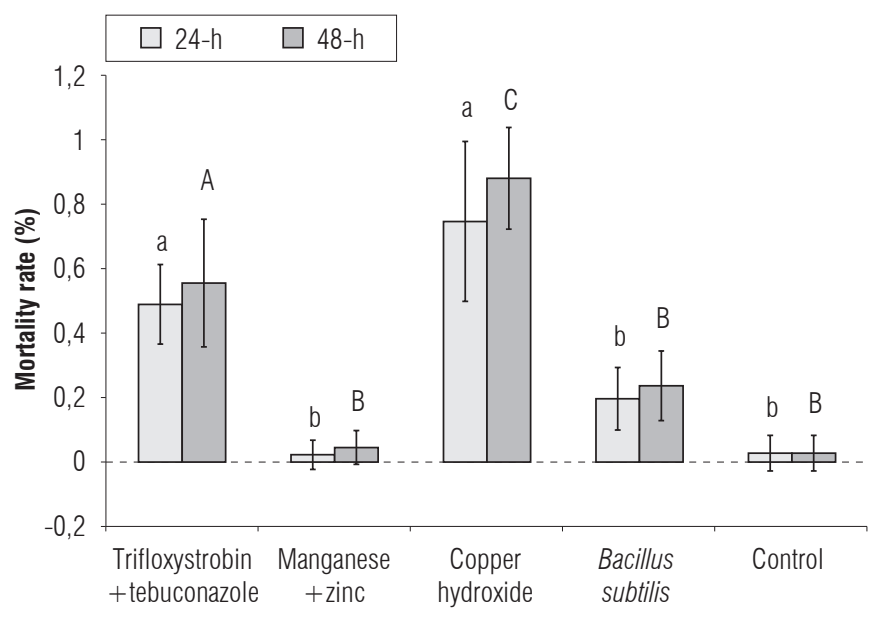

Figure 2. Mortality rate of Melipona quadrifasciata in different treatments with fungicides and evaluation periods. Lowercase letters differentiate statistical significance for the treatment evaluated for $24 \mathrm{~h}$, and capital letters for $48 \mathrm{~h}(P \leq 0.05)$.

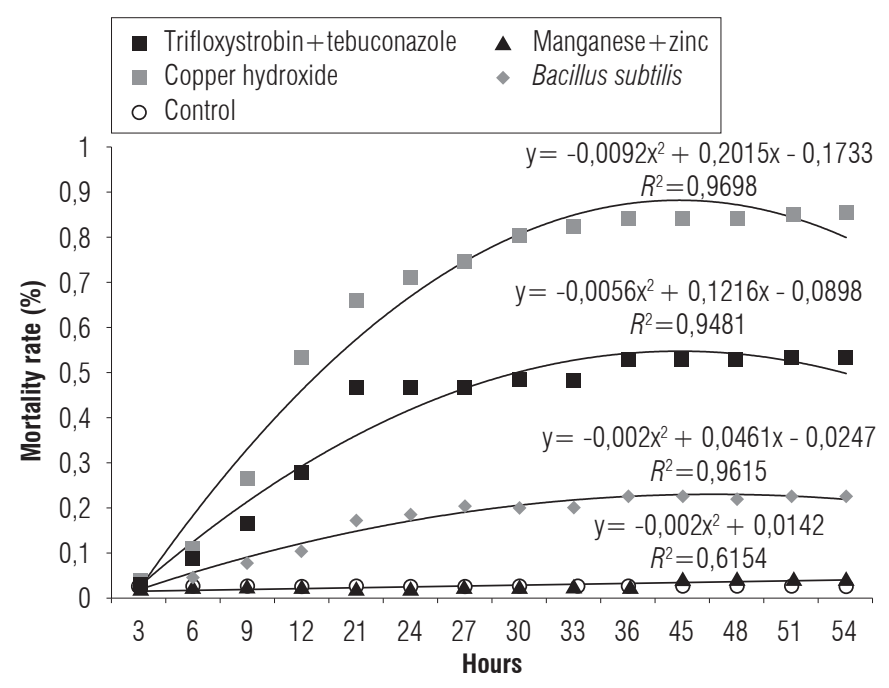

Figure 3. Average mortality rate of Melipona quadrifasciata in different fungicide treatments and $54 \mathrm{~h}$ of evaluation.

The same treatments that provided the lowest pollen load also presented the lowest percentage of pollination marks in the flowers. The treatments containing trifloxystrobin reduced the number of pollination marks by $44 \%$. The number of seeds varied among the treatments, different from the pollen load, but still a reflection of pollination. The treatments with the lower amount of seeds were treatment 5 ( $B$. subtilis + copper hydroxide), 6 (acibenzolar), and 10 (trifloxystrobin+tebuconazole $+B$. subtilis + copper hydroxide). Despite exhibiting the lowest pollen load, treatment 9 (trifloxystrobin $+B$. subtilis) provided one of the highest number of seeds, with gains over $24 \%$, as compared to that obtained in the worst treatment (T6 or acibenzolar-S-methyl).

The treatments that provided greater production in mass and larger fruits were treatment 1 (control), 2 (B. subtilis 12), 3 (B. subtilis 6), 4 (copper hydroxide), 7 (trifloxystrobin $+B$. subtilis ) and 10 (trifloxystrobin+tebuconazole+ $B$. subtilis + copper hydroxide). The better treatments, in regards to all of the variables assessed, were the control treatment, the biological interventions (B. subtilis 6 and 12 ) and the treatments using copper hydroxide. Treatment 10, with trifloxystrobin, tebuconazole, B. subtilis and copper, also 
presented gains compared to the treatments that used the same chemical without Bacillus. Treatment 6 (acibenzolar), 8 (copper hydroxide + manganese and zinc) and 9 (propineb + trifloxystrobin + tebuconazole) provided the worst results for pollen load, seed and fruit mass, except when combined with B. subtilis.
The agrochemical application frequency was important for bee mortality and tomato production. A higher number of applications of a given treatment can cause a lower occurrence of pollination marks and pollen grains on the stigma and lead to fruit with a lower number of seeds, mass, and size (Fig. 3 and 4).

Table 2. Treatments carried out on the tomato plants (Solanum lycopersicum) and results obtained for the pollen load (Pollen), pollination marks (Marks), mark distance, number of seeds, mass, height and width (Height $\times$ Width). Means with different letters indicate significant difference according to the Tukey test $(P \leq 0.05)(F(10,315)=2.823 ; P=0.002)$.

\begin{tabular}{|c|l|c|c|c|c|c|}
\hline Treatment & \multicolumn{1}{|c|}{ Active ingredient } & Pollen & Marks (\%) & Number of seeds & Mass (g) & $\begin{array}{c}\text { Height } \times \text { Width } \\
\text { (Size; mm) }\end{array}$ \\
\hline T1 & - & $164.77 \pm 20.41 \mathrm{a}$ & $0.92 \pm 0.09 \mathrm{a}$ & $205.77 \pm 20.33 \mathrm{a}$ & $153.04 \pm 11.07 \mathrm{a}$ & $3,821.28 \pm 480.56 \mathrm{ab}$ \\
\hline T2 & Bacillus subtilis & $143.25 \pm 29.45 \mathrm{a}$ & $0.89 \pm 0.15 \mathrm{a}$ & $203.23 \pm 46.71 \mathrm{~b}$ & $167.54 \pm 25.68 \mathrm{~b}$ & $3,943.46 \pm 610.49 \mathrm{ab}$ \\
\hline T3 & Bacillus subtilis & $168.79 \pm 39.31 \mathrm{a}$ & $0.85 \pm 0.19 \mathrm{a}$ & $225.58 \pm 90.30 \mathrm{~b}$ & $164.51 \pm 15.0 \mathrm{~b}$ & $3,886.42 \pm 605.60 \mathrm{ab}$ \\
\hline T4 & Copper hydroxide & $168.35 \pm 41.98 \mathrm{a}$ & $0.96 \pm 0.06 \mathrm{~b}$ & $201.35 \pm 22.36 \mathrm{~b}$ & $167.85 \pm 32.49 \mathrm{~b}$ & $4,005.5 \pm 626.16 \mathrm{a}$ \\
\hline T5 & $\begin{array}{l}\text { Bacillus subtilis and copper } \\
\text { hydroxide }\end{array}$ & $205.46 \pm 15.92 \mathrm{~b}$ & $0.96 \pm 0.05 \mathrm{~b}$ & $177.48 \pm 18.52 \mathrm{c}$ & $145.30 \pm 17.16 \mathrm{ac}$ & $3,731.71 \pm 492.96 \mathrm{bc}$ \\
\hline T6 & Acibenzolar-S-methyl & $147.68 \pm 24.18 \mathrm{a}$ & $0.97 \pm 0.21 \mathrm{~b}$ & $174.16 \pm 25.93 \mathrm{c}$ & $137.35 \pm 29.12 \mathrm{c}$ & $3,537 \pm 613.83 \mathrm{c}$ \\
\hline T7 & $\begin{array}{l}\text { (Trifloxystrobin+tebucona- } \\
\text { zole) Bacillus subtilis }\end{array}$ & $122.09 \pm 30.88 \mathrm{c}$ & $0.66 \pm 0.28 \mathrm{c}$ & $233.28 \pm 36.26 \mathrm{a}$ & $155.70 \pm 4.60 \mathrm{a}$ & $3,734.5 \pm 326.52 \mathrm{bc}$ \\
\hline T8 & $\begin{array}{l}\text { Copper hydroxide } \\
+ \text { Mancozeb }\end{array}$ & $210.15 \pm 77.67 \mathrm{~b}$ & $1 \pm 0.0 \mathrm{~b}$ & $221.34 \pm 37.64 \mathrm{a}$ & $134.20 \pm 17.68 \mathrm{c}$ & $3,487.92 \pm 448.03 \mathrm{c}$ \\
\hline T9 & $\begin{array}{l}\text { Propineb+ (trifloxystrobin } \\
+ \text { tebuconazole) }\end{array}$ & $116.19 \pm 20.37 \mathrm{c}$ & $0.88 \pm 0.10 \mathrm{a}$ & $204.25 \pm 31.71 \mathrm{ab}$ & $139.50 \pm 18.76 \mathrm{c}$ & $3,595.23 \pm 537.39 \mathrm{c}$ \\
\hline T10 & $\begin{array}{l}\text { (Trifloxystrobin+tebucona- } \\
\text { zole) + Bacillus subtilis } \\
+ \text { copper hydroxide }\end{array}$ & $110.74 \pm 12.35 \mathrm{c}$ & $0.88 \pm 0.12 \mathrm{a}$ & $190.10 \pm 21.02 \mathrm{bc}$ & $151.84 \pm 17.80 \mathrm{a}$ & $3,785.21 \pm 452.03 \mathrm{bc}$ \\
\hline
\end{tabular}

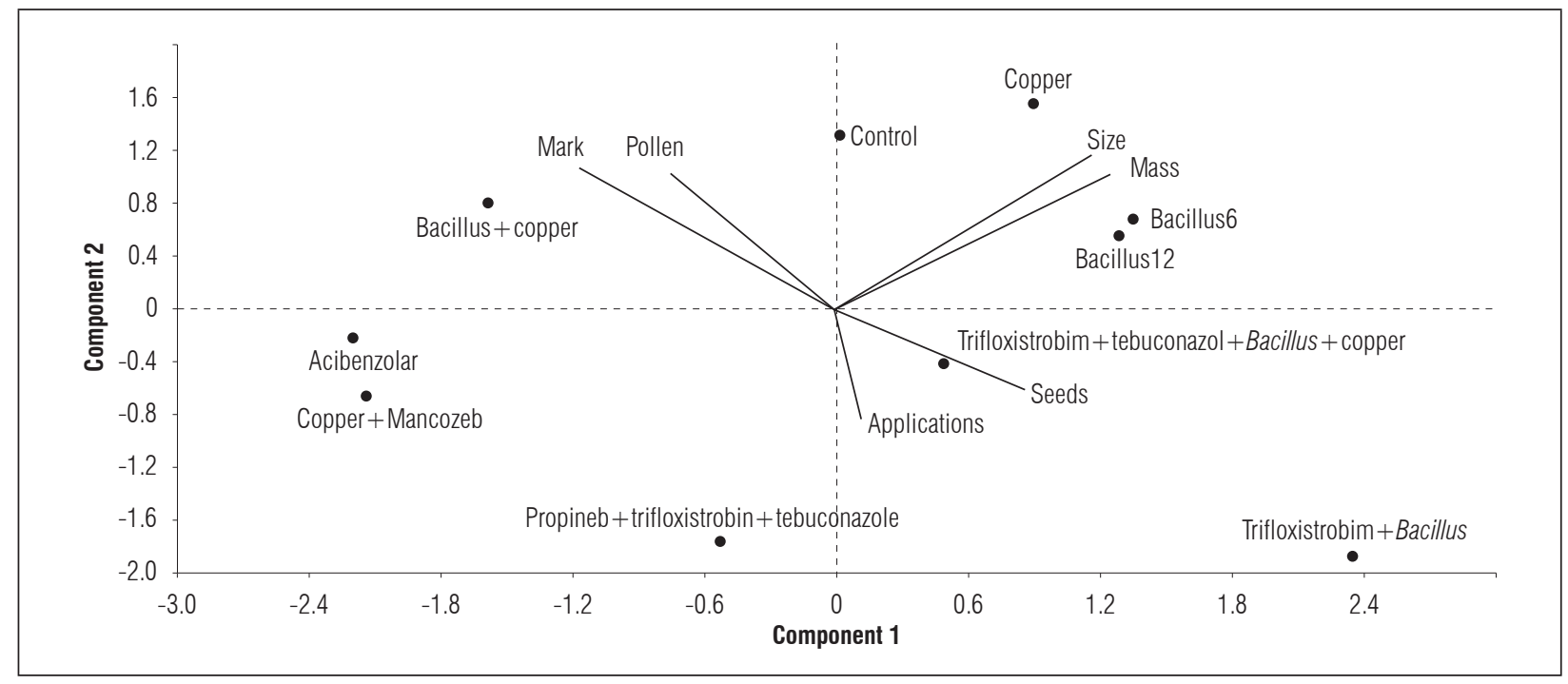

Figure 4. Principal components analysis with the different fungicide treatments, pollination characteristics and fruit yield in tomato (Solanum lycopersicum) (1 ${ }^{\text {st }}$ Component - Pollen: 41.46\%; $2^{\text {nd }}$ Component - Mark: 23.38\%; Seed: 16.53\%; Mass: $15.17 \%$; Fruit size: $2.73 \%$ and Applications: $0.72 \%)$. 


\section{DISCUSSION}

The results on the mortality rate of Melipona quadrifasciata is congruent with the lethal dose effects $\left(\mathrm{LD}_{50}\right)$ of some fungicides described for Apis mellife$r a$ as described in the package leaflet of the studied pesticides. The fungicide Kocide ${ }^{\circledR}$ (copper hydroxide-based) had a $\mathrm{LD}_{50} 48 \mathrm{~h}$ after the intake of only 8.15 $\mu \mathrm{g} \mathrm{kg}{ }^{-1}$. However, the same lethal dose for contact was $100 \mu \mathrm{g} \mathrm{kg}^{-1}$. The fungicide Nativo ${ }^{\circledR}$ (trifloxystrobin + tebuconazole-based) exhibited a $\mathrm{LD}_{50}$ for ingestion of $273.86 \mu \mathrm{g} / \mathrm{bee}$ and $298.4 \mu \mathrm{g} / \mathrm{bee}$ for contact. Mancozeb presented a $\mathrm{LD}_{50}$ of $100 \mu \mathrm{g} /$ bee, without reference to contact or ingestion, as described in the leaflet of each pesticide. The units may vary since they are established by the manufacturer.

Copper is a widely used component in agriculture in the form of sulfates and hydroxides and is allowed in the production of organic foods because it is considered non-toxic and not harmful to the environment. However, this statement has been challenged in regards to bees. In this study, the toxicity and mortality of the bees as the result of the ingestion of copper (copper hydroxide) were considered high, even when compared with trifloxystrobin and tebuconazole based products. Barbosa et al. (2015) studied the effects of copper-based fungicides on bees in bioassays with the stingless bee Friesella schrottkyi (Friese) and reported high mortality rates for worker bees, but low rates when compared to other pesticides, such as spinosad (insecticide).

The fungicides evaluated in this study with the highest $M$. quadrifasciata mortality rates are considered as lethal as some insecticides that are more harmful to bees. Jacob et al. (2013) tested fipronil in Scaptotrigona postica and Costa et al. (2015) tested imidacloprid in $M$. scutellaris; both found mortality results similar to that reported in this study for fungicides. This shows that fungicides can be as harmful to bees as insecticides even though that is not their purpose. Here, we point out that, even though they are different species or different methodologies, these results are important, showing the impacts of agrochemicals on bees.

The results obtained in this study only show the acute effects on bees, occurring approximately $50 \mathrm{~h}$ after contact of the bees with the fungicide. Chronic effects may also occur, but should be investigated more thoroughly. The fungicides tested on $M$. quadrifasciata were only evaluated by ingestion with sugar syrup since sole contact of the product with the exoskeleton of the insect may cause other effects, such as symptoms of malnutrition, susceptibility to pathogens, and orientation disturbance in flight and foraging. Agrochemicals, even when used in low frequency or concentration levels, may cause lethal or sublethal effects, with behavioral changes that affect pollinator choices (Thompson, 2003).

Other products, such as Serenede ${ }^{\circledR}$ (based on B. subtilis) and Bion ${ }^{\circledR}$ (acibenzolar-S-methyl), did not show predetermined $\mathrm{LD}_{50}$ for any bee species (including Apis mellifera). Ngugi et al. (2005) used Apis mellifera as vectors of Bacillus subtilis and pollinators of blueberries in a greenhouse. In this case, B. subtilis was used to fight a fungus common in the culture, Monilinia vaccinii-corymbosi (Reade) Honey.

Copper hydroxide (Kocide ${ }^{\circledast}$ ) is a pesticide with a high mortality rate among $M$. quadrifasciata bees, but did not considerably reduce the number of bite marks in the anthers of the tomato flowers. This lack of bee visitation marks on the tomato flowers may have been due to the residue of the pesticide remaining on the flowers as a powder and not as a solution (as the applied in this study), which may reduce the product's potential harm to insects. Kocide ${ }^{\circledR}$ did not affect bee visitation in this research, but this does not mean that residue in flowers cannot harm bees after pollen collection, with lethal or sub-lethal effects on bee development.

Unlike the toxicity presented by copper hydroxide, Mancozeb $^{\circledR}$ (Carbamate with manganese and zinc salts) was not toxic for $M$. quadrifasciata, providing results similar to the control treatment. If Man$\mathrm{cozeb}^{\circledR}$ is considered efficient in controlling fungal infections in tomato, it is an agrochemical option with less impact on pollinating agents.

For pollen load, the alternating trifloxystrobin+tebuconazole and B. subtilis + copper hydroxide applications reduced the visitation effect and increased pollination, as compared to the application of only trifloxystrobin + rebuconazole. The concern about the effects of pesticides on pollinating bees is almost always associated with insecticides because of their direct effect on insects (Carvalho et al., 2009). Still, fungicides comprise a large class of chemicals widely used in agriculture, especially in tomato crops (Vale et al., 2013).

Sanchez-Bayo and Goka (2014) studied pollen grains contaminated with agrochemicals and found that 
fungicides are more frequent in contaminated pollen. This finding reinforces the need for specific studies on the effect of fungicides on pollinating bees in agricultural crops. Thus, this biological control was efficient in fighting fungal diseases and did not affect the bees that pollinated the crop. Ngugi et al. (2005) reported that B. subtilis did not affect the deposition of pollen grains on stigma, nor the growth of the pollen tube, meaning pollination occurred as expected under natural conditions. Bees are insects that naturally interact with fungi and microorganisms. When these microorganisms are not directly pathogenic to bees, the groups may interact in equilibrium (Mcfrederick et al., 2014). Therefore, the interaction between $B$. subtilis and bees may be harnessed for agricultural purposes (Park et al., 2013).

Pettis et al. (2013) detected about 35 agrochemicals in pollen grains from almond, apple, blueberry, cranberry, pumpkin, melon and cucumber crops, most of which were insecticides followed by fungicides. The authors concluded that a greater amount of pesticide on pollen leads to an increased chance of pollinators being infected by the fungus Nosema spp., which is considered very harmful to bees (Apis mellifera and natives). Thus, they highlighted the relevance of verifying sub-lethal effects of fungicides and other products used in agriculture on bees.

Some fungicides can have a major impact on crop pollination by reducing the number of visits to crop flowers, by repelling bees or affecting plant physiology and, consequently, reducing pollen viability and availability of nutritious food (Solomon and Hooker, 1989; Riedl et al., 2006). Captan ${ }^{\circledR}$ is a fungicide widely used in apple trees and may cause reduced visitation by reducing the attractiveness of flowers to bees through the presence of harmful chemical compounds. Thus, Captan ${ }^{\circledR}$ reduces foraging, causes morphogenic defects in adults exposed in the larval stage (on legs, wings and body) and increases larval mortality (Mussen et al., 2004; Freitas and Pinheiro, 2010).

In organic tomato crops in Piauí, $76 \%$ more bees were found than in conventional crops that use pesticides. This shows that the products may be affecting the pollinator community and visitation, with lethal or sublethal effects (Santos and Nascimento, 2011). The use of pesticides during flowering in the cultivation of mangoes (Mangifera indica) in the sub-middle San Francisco Valley reduced the frequency of bee visits by $50 \%$ and diptera by $20 \%$ (Siqueira, 2008).
In this study, the frequency of the application of fungicides was relevant in the tomato crop in terms of bees. The application frequency was related to seed production and fruit characteristics in the principal components analysis. The agrotoxic agent applied at a higher frequency, even when biological (Bacillus subtilis), reduced bee visitation more intensely than products considered more toxic (acibenzolar-S-metil) applied with a lower frequency. This pattern reinforces the relationship between the application frequency of agrochemicals and manufacturer's recommendation, making it vital to check the period established by the manufacturer for the product to be re-applied to a crop. The application frequency of agrochemicals, time of day and forms of application are relevant for the effects that products will have on targets (insect pests and fungi) and on non-target insects, such as bees (Franceschinelli et al., 2017). These non-target effects are relevant research topics for future studies. Thus, a greater number of applications of pesticides on tomato flowers leads to a lower number of visits from bees to flowers. Consequently, there will be a smaller amount of pollen grains deposited on the stigmas, affecting fruit quality and yield (Nunes-Silva et al., 2013; Silva-Neto et al., 2013).

The effects of different pesticides differ among products from different classes (e.g., insecticides, fungicides, herbicides and others) in terms of their mechanisms of action on bees. Insecticides affect bees as neurotoxic agents, affecting the transmission of the nerve impulse, interferes with growth, damaging the transformation of the stages of the insects, and affects metabolic processes, such as cellular respiration and death. For the fungicides, the direct and indirect effects verified for the bees and the mechanisms of action are not known (Tomé et al., 2015; Lima et al., 2016; Rodrigues et al., 2016). Thus, more research on pesticides (insecticides and other classes) and agricultural crop pollinators are needed.

In conclusion, Kocide (copper hydroxide) and Nativo (trifloxystrobin and tebuconazole) provided the highest mortality rates for Melipona quadrifasciata. The treatments with Mancozeb and Serenade and the control treatment did not differ from each other.

trifloxystrobin and tebuconazole were the most repellent active ingredients for bee pollination in the tomato crop. Fruits from the plants treated with $\mathrm{Ba}$ cillus subtilis and copper hydroxide were larger and had higher mass. 


\section{ACKNOWLEDGMENTS}

The authors are grateful for the support provided by the Federal Institute of Goiás (IFG) for carrying out the research addressed in this paper and for resources for its publication. The first author is agroecologist technologist in the same institution.

Conflict of interests: the manuscript was prepared and reviewed with the participation of the authors, who declare that there exists no conflict of interest that puts the validity of the presented results at risk.

\section{BIBLIOGRAPHIC REFERENCES}

Artz, D.R. and T.L. Pitts-Singer. 2015. Effects of fungicide and adjuvant sprays on nesting behavior in two managed solitary bees, Osmia lignaria and Megachile rotundata. PloS One 10, e0135688. Doi: 10.1371/journal. pone.0135688

Barbosa, W.F., G. Smagghe, and R.N.C. Guedes. 2015. Pesticides and reduced-risk insecticides, native bees and pantropical stingless bees: pitfalls and perspectives. Pest. Manag. Sci. 71(8), 1049-1053. Doi: 10.1002/ ps. 4025

Carvalho, S.M., G.A. Carvalho, C.F. Carvalho, J.S.S. BuenoFilho, and A.P.M. Baptista. 2009. Toxicidade de acaricidas/inseticidas empregados na citricultura para a abelha africanizada Apis mellifera L., 1758 (Hymenoptera: Apidae). Arq. Inst. Biol. 76(4), 597-606.

Costa, L.M., T.C. Grella, R.A. Barbosa, O. Malaspina, and R.C.F. Nocelli. 2015. Determination of acute lethal doses $\left(\mathrm{LD}_{50}\right.$ and $\left.\mathrm{LC}_{50}\right)$ of imidacloprid for the native bee Melipona scutellaris Latreille, 1811 (Hymenoptera: Apidae). Sociobiol. 62(4), 578-582. Doi: 10.13102/sociobiology.v62i4.792

Dafni, A., E. Pacini, and M. Nepi. 2005. Pollen and stigma biology. pp 83-142. In: Dafni, A., P. Kevan, and B. Husband (eds.). Practical pollination biology. Ontario, Canada.

Degrandi-Hoffman, G., Y. Chen, E.W. Dejong, M.L. Chambers, and G. Hidalgo. 2015. Effects of oral exposure to fungicides on honey bee nutrition and virus levels. J. Econ. Entomol. 251(6), 1-11. Doi: 10.1093/jee/tov251

Embrapa. 2006. Sistema brasileiro de classificação de solos. $2^{\text {nd }}$ ed. Rio de Janeiro, Brazil.

Fletcher, M. and L. Barnett. 2003. Bee poisoning incidents in the United Kingdom. Bull. Insectol. 56, 141-145.

Franceschinelli, E.V., M.A. Elias, L.L. Bergamini, C.M. Silva-Neto, and E.R. Sujii. 2017. Influence of landscape context on the abundance of native bee pollinators in tomato crops in Central Brazil. J. Ins. Cons. 21(4), 715-726. Doi: 10.1007/s10841-017-0015-y

Freitas, B.M. and J.N. Pinheiro. 2010. Efeitos sub-letais dos pesticidas agrícolas e seus impactos no manejo de polinizadores dos agroecossistemas brasileiros. Oecologia 14, 282-298. Doi: 10.4257/oeco.2010.1401.17

Gill, R.J. and N.E. Raine. 2014. Chronic impairment of bumblebee natural foraging behaviour induced by sublethal pesticide exposure. Funct. Ecol. 28(1), 14591471. Doi: 10.1111/1365-2435.12292

Hopwood, J., M. Vaughan, M. Shepherd, D. Biddinger, E. Mader, S.H. Black, and C. Mazzacano. 2012. Are neonicotinoids killing bees? A review of research into the effects of neonicotinoid insecticides on bees, with recommendations for action. Xerces Society for Intervertebrate Conservation, Portland, OR, USA.

Jacob, C.R.O., H.M. Soares, S.M. Carvalho, R.C.F. Nocelli, and O. Malaspina. 2013. Acute toxicity of fipronil to the stingless bee Scaptotrigona postica Latreille. Bull. Environ. Contam. Toxicol. 90(1), 69-72. Doi: 10.1007/ s00128-012-0892-4

Johnson, R.M., L. DahlGren, B.D. Siegfried, and M.D. Ellis. 2013. Acaricide, fungicide and drug interactions in honey bees (Apis mellifera). PloS One 8, e54092. Doi: 10.1371/journal.pone.0054092

Lima, M.A.P., G.F. Martins, E.E. Oliveira, and R.N.C. Guedes. 2016. Agrochemical-induced stress in stingless bees: peculiarities, underlying basis, and challenges. J. Comp. Physiol. A. 202(9-10), 733-747. Doi: 10.1007/ s00359-016-1110-3

McFrederick, O.S., G. Ulrich, R. Mueller, and R. James. 2014. Interactions between fungi and bacteria influence microbial community structure in the Megachile rotundata larval gut. Proc. R. Soc. Lond. B. Biol. Sci. 281(1779), 1-8.

Morandin, L.A., T.M. Laverty, and P.G. Kevan. 2001a. Bumble bee (Hymenoptera: Apidae) activity and pollination levels in commercial tomato greenhouses. J. Econ. Entomol. 94(2), 462-467. Doi: 10.1603/0022-0493-94.2.462

Morandin, L.A., T.M. Laverty, and P.G. Kevan. 2001b. Effect of bumble bee (Hymenoptera: Apidae) pollination intensity on the quality of greenhouse tomatoes. J. Econ. Entomol. 94(1), 172-179. Doi: 10.1603/0022-0493-94.1.172

Mussen, E.C.M., I. Julio, E. Lopez, and C.Y. Peng. 2004. Effects of selected fungicides on growth and development of larval honey bees, Apis mellifera L. (Hymenoptera: Apidae). Environ. Entomol. 33(5), 1151-1154. Doi: 10.1603/0046-225X-33.5.1151

Ngugi, H.K., S. Dedej, K.S. Delaplane, A.T. Savelle, and H. Scherm. 2005. Effect of flowerapplied Serenade biofungicide (Bacillus subtilis) on pollination-related variables in rabbiteye blueberry. Biol Control 33(1), 32-38. Doi: 10.1016/j.biocontrol.2005.01.002 
Nunes-Silva, P., M. Hnrcir, L. Shipp, V.L. Imperatriz-Fonseca, and P.G. Kevan. 2013. The behaviour of Bombus impatiens (Apidae, Bombini) on tomato (Lycopersicon esculentum Mill., Solanaceae) flowers: pollination and reward perception. J. Pollinat. Ecol. 11(5), 33-40.

Park, H.H., J.J. Kim, K.H. Kim, and S.G. Lee. 2013. Dissemination of Bacillus subtilis by using bee-vectoring technology in cherry tomato greenhouses. Korean J. Appl. Entomol. 52(4), 357-364. Doi: 10.5656/ KSAE.2012.09.0.046

Peel, M.C., L.F. Brian, and T.A. McMahon. 2007. Updated world map of the Köppen-Geiger climate classification. Hydrol. Earth Syst. Sci. Discuss. 4(2), 439-473. Doi: 10.5194/hessd-4-439-2007

Pettis, J.S., E.M. Lichtenberg, M. Andree, J. Stitzinger, and R. Rose. 2013. Crop pollination exposes honey bees to pesticides which alters their susceptibility to the gut pathogen Nosema ceranae. PLoS One 8, e70182. Doi: 10.1371/journal.pone.0070182

Pignati, W.A., A.N.D.S. Lima, S.S.D. Lara, M.L.M. Correa, J.R. Barbosa, L.H.D.C. Leão, and M.G. Pignatti. 2017. Spatial distribution of pesticide use in Brazil: a strategy for Health Surveillance. Cien. Saude Colet. 22(10), 3281 3293. Doi: 10.1590/1413-812320172210.17742017

Riedl, H., E. Johansen, L. Brewer, and J. Barbour. 2006. How to reduce bee poisoning from pesticides. Oregon State University; University of Idaho; Washington State University, Corvallis, OR, USA.

Rocha, M.C.L.S.A. 2012. Efeitos dos agrotóxicos sobre as abelhas silvestres no Brasil: proposta metodológica de acompanhamento. Instituto Brasileiro do Meio Ambiente e dos Recursos Naturais Renováveis, Brasilia, Brazil.

Rodrigues, C.G., A.P. Kruger, W.F. Barbosa, and R.N.C. Guedes. 2016. Leaf fertilizers affect survival and behavior of the neotropical stingless bee Friesella schrottkyi (Meliponini: Apidae: Hymenoptera). J. Econ. Entomol. 109(30), 1001-1008. Doi: 10.1093/jee/tow044

Sanchez-Bayo, F. and K. Goka. 2014. Pesticide residues and bees - a risk assessment. PLoS ONE 9, e94482. Doi: 10.1371/journal.pone.0094482
Santos, A.B. and F.S. Nascimento. 2011. Diversidade de visitantes florais e potenciais polinizadores de Solanum lycopersicum (Linnaeus) (Solanales: Solanaceae) em cultivos orgânicos e convencionais. Neotrop. Biol. Conserv. $6 \mathrm{a}(3), 162-169$.

Silva-Neto, C.M., F.G. Lima, B.B. Gonçalves, L.L. Bergamini, B.A. Bergamini, M.A.S. Elias, and E.V. Franceschinelli. 2013. Native bees pollinate tomato flowers and increase fruit production. J. Pollinat. Ecol. 11(6), 41-45.

Silva-Neto, C.M., E.V. Franceschinelli, L.L. Bergamini, M.A.S. Elias, J.M. Morais, G.L. Moreira, B.A. and Bergamini. 2016. High species richness of native pollinators in brazilian tomato crops. Braz. J. Biol. 77(3), 506-513. Doi: 10.1590/1519-6984.17515

Siqueira, K.M.N. 2008. Estudo comparativo da polinização de Mangifera indica L. em cultivo convencional e orgânico na região do Vale do Submédio do São Francisco. Rev. Bras. Fruti. 30, 303-310. Doi: 10.1590/ S0100-29452008000200006

Solomon, M.G. and K.J.M. Hooker. 1989. Chemical repellents for reducing pesticide hazard to honeybees in apple orchards. J. Apic. Res. 28(4), 223-227. Doi: 10.1080/00218839.1989.11101188

Spadotto, C.A., M.A.F. Gomes, L.C. Luchini, and M.M. Andrea. 2004. Monitoramento de risco ambiental de agrotóxicos: princípios e recomendações. Jaguaríuna, São Paulo-SP, Brazil.

Thompson, H.M. 2003. Behavioural effects of pesticides in bees - their potential for use in risk assessment. Ecotoxicol. 12(1-4), 317-330. Doi: 10.1023/A:1022575315413

Tomé, H.V.V., W.F. Barbosa, A.S. Correa, L.M. Gontijo, G.F. Martins, and R.N.C Guedes. 2015. Reduced risk insecticides in Neotropical stingless bee species: impact on survival and activity. Ann. Appl. Biol. 167(2), 186-196. Doi: 10.1111/aab.12217

Vale, F.X.R., C.A. Lopes, and M.A.R. Alvarenga. 2013. Doenças fúngicas, bacterianas e causadas por nematoides. pp. 275-326. In: Alvarenga, M.A.R. (ed.). Tomate. Produção em campo, casa de vegetação e hidroponia. Editora Universitária de Lavras, Lavras-MG, Brazil. 